\title{
Should we do early and frequent charcoal hemoperfusion in phenytoin toxicity?
}

\author{
Jyoti Narayan Sahoo, Mohan Gurjar ${ }^{1}$
}

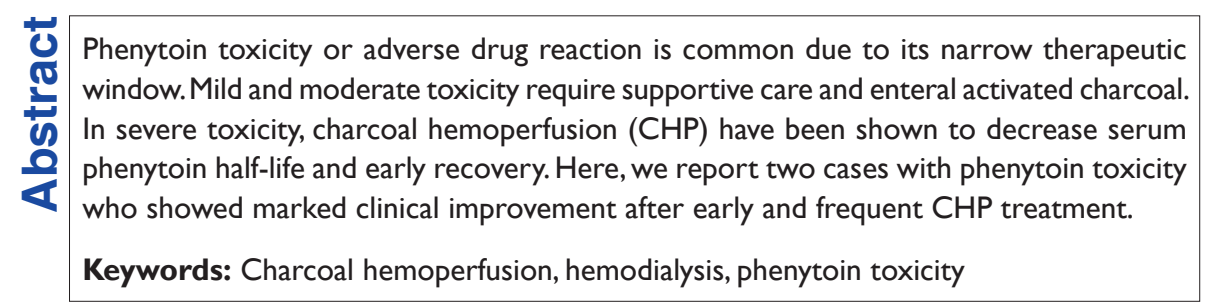

\section{Introduction}

Phenytoin toxicity is commonly seen in renal and hepatic compromise patient and with massive ingestion. ${ }^{[1]}$ Clinical feature of phenytoin toxicity are reversible and mostly correlate with its serum concentration. Common clinical features are nystagmus, diplopia, ataxia, confusion, disorientation, and hyperactivity; while in severe toxicity leads to coma and seizure. ${ }^{[1,2]}$ In the absence of antidote, clinical observation and supportive care is required in patients with mild to moderate poisoning; while in the case of sever severe toxicity, there are few case reports where charcoal hemoperfusion (CHP) have been tried, with both successful and unsuccessful reports. Here, we presented two cases of phenytoin toxicity in whom repeated CHP done with a successful outcome.

\section{Case Reports}

\section{Case 1}

A 58-year-old man with a known case of seizure

\section{From:}

Departments of Critical Care Medicine, Apollo Hospital, Jubilee Hills, Hyderabad, Telangana, ${ }^{1}$ Critical Care Medicine, Sanjay Gandhi Postgraduate Institute of Medical Sciences, Lucknow, Uttar Pradesh, India

\section{Correspondence:}

Dr. Jyoti Narayan Sahoo, Apollo Hospital, Jubilee Hills, Hyderabad,

Telangana, India.

E-mail: jyotinarayansgpgi@gmail.com

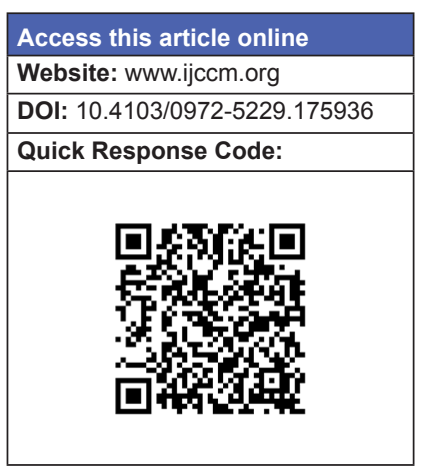

disorder on phenytoin (100 mg BD) and alcoholic liver disease was admitted to the emergency department with a history of altered sensorium and fall. There was an alleged history of intake of phenytoin tablet of unknown amount. On arrival his vital parameter were heart rate (HR)-88/ min, blood pressure (BP)-100/60 mm of $\mathrm{Hg}$, relative risk (RR) $-30 / \mathrm{min}, \mathrm{SpO}_{2}-94 \%$ and neurological examination revealed Glasgow Coma Score (GCS) - 9 (E2V2M5) and both pupil $2 \mathrm{~mm}$ and reacting to light. Computed tomography (CT) brain was normal, and chest X-ray showed infiltrate in right lower lobe suggestive of aspiration pneumonia. Laboratory blood investigation was normal except serum albumin $2.4 \mathrm{~g} / \mathrm{dl}$ and total serum phenytoin level of $54 \mu \mathrm{g} / \mathrm{ml}$. Initially, the patient was managed with enteral activated charcoal. As the sensorium worsened patient was intubated and mechanically ventilated. CHP was started for $3 \mathrm{~h}$ and after hemoperfusion patient sensorium improved, but again worsen in few hours.

This is an open access article distributed under the terms of the Creative Commons Attribution-NonCommercial-ShareAlike 3.0 License, which allows others to remix, tweak, and build upon the work non-commercially, as long as the author is credited and the new creations are licensed under the identical terms.

For reprints contact: reprints@medknow.com

How to cite this article: Sahoo JN, Gurjar M. Should we do early and frequent charcoal hemoperfusion in phenytoin toxicity? Indian J Crit Care Med 2016;20:123-5. 
Post CHP serum total phenytoin level was $44.5 \mu \mathrm{g} / \mathrm{ml}$. Further two secessions of CHP were done in a gap of $24 \mathrm{~h}$, and the total phenytoin level decreased to $24 \mu \mathrm{g} / \mathrm{ml}$ with no improve in sensorium [Table 1]. As the patient required prolonged mechanical ventilation for aspiration pneumonia, further CHP was not done. After 6 days, patient sensorium improved along with respiratory parameter and was weaned from mechanical ventilation and extubated. On the $6^{\text {th }}$ day, patient total serum phenytoin level was $16 \mu \mathrm{g} / \mathrm{ml}$ and was started on levetiracetam. On the $7^{\text {th }}$ day, patient was transferred to the ward.

\section{Case 2}

A 64-year-old man with a known case of seizure disorder on phenytoin $(200 \mathrm{mg}$ OD, sustain release tablet) was found in an altered sensorium state by his relative and was brought to the emergency department. History of normal sensorium $8 \mathrm{~h}$ prior to altered sensorium and general examination revealed HR-64/min, BP-108/54 mm of Hg, RR-38/min with labored respiration, oxygen saturation of $94 \%$ and central nervous system examination showed both pupil of $2 \mathrm{~mm}$ in size and reacting to light with a GCS of 8/15 (E2V2M4). Further history revealed probable intake of 40-50, $200 \mathrm{mg}$ phenytoin tablet. The patient was intubated and mechanical ventilated for airway protection. CT scan of the brain was normal. Further investigation showed total serum phenytoin level of $63 \mu \mathrm{g} / \mathrm{ml}$. Diagnosis of phenytoin poisoning was made and CHP was started (13 h after last found conscious or in a normal state). During the $3 \mathrm{~h}$ period of CHP patient gradually regained consciousness and at the end patient GCS improved from 8 (E1V1M4) to 9 (E3VTM6). Post CHP total serum phenytoin level decreased to $52 \mu \mathrm{g} / \mathrm{ml}$ but the sensorium gradually deteriorated to pre-CHP level within $2 \mathrm{~h}$. The second cycle of CHP was started after $8 \mathrm{~h}$ of the first cycle for $3 \mathrm{~h}$. The patient response was same to the first and the total serum phenytoin level decreased to $40 \mu \mathrm{mg} / \mathrm{ml}$. Hence, we decided to do hemoperfusion every eight hourly till the total phenytoin level comes down to $<30 \mu \mathrm{mg} / \mathrm{ml}$. A total of 4 cycles of hemoperfusion was done, and the last phenytoin level was $19 \mu \mathrm{g} / \mathrm{ml}$ [Table 1]. There was no significant complication apart from thrombocytopenia (1.9 lacks $/ \mu \mathrm{ml}$ to $32,000 / \mu \mathrm{ml})$ and leukopenia $(10,800$ cells/ $\mathrm{cmm}$ to 3300 cells/ $\mathrm{cmm})$. The patient was weaned from mechanical ventilation and extubated on the $3^{\text {rd }}$ day after optimization of serum electrolyte. The antiepileptic medication was changed to leviteracetam and patient was discharged from Intensive Care Unit the following day.

\section{Discussion}

Hemodialysis is used to treat selected drugs intoxication. To be removed by hemodialysis the drugs must have certain pharmacokinetics properties such as molecular weight (MW) less than 2000 Dalton, protein binding rate $<50 \%$, the volume of distributions $<0.75 \mathrm{~L} / \mathrm{kg}$ and high water solubility. ${ }^{[3]}$ Serum albumin has an MW of 66,200 Da, so drugs bound to albumin is not cleared by hemodialysis. Phenytoin has an MW of 272 Dalton, the volume of distribution of $0.7 \mathrm{~L} / \mathrm{kg}$, extensively bound (90\%) to serum albumin and $10 \%$ of free drug is responsible for its action. ${ }^{[1]}$ The plasma half-life ranges from 6 to $24 \mathrm{~h}$ at therapeutic

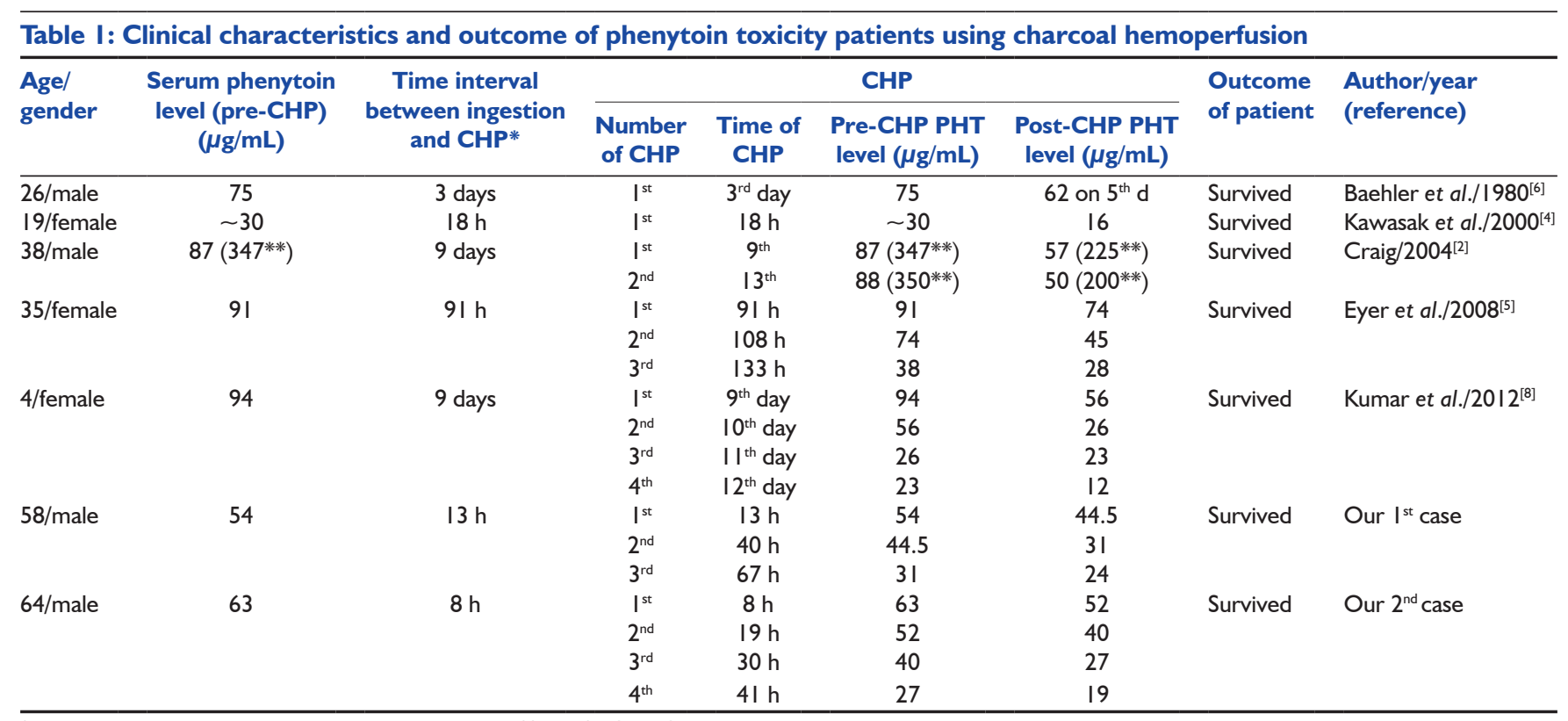

*Time since the patient was seen with normal sensorium; ** $\mu$ mol/L. CHP: Charcoal hemoperfusion; PHT: Phenytoin 
plasma concentration $(10-20 \mu \mathrm{g} / \mathrm{ml})$ but increases disproportionately as the plasma concentration increase. ${ }^{[1,4]}$ Phenytoin is metabolized by hepatic enzyme and excreted via the kidney, but the hepatic enzyme is readily saturated at high level (changing from first order kinetics to zero order at high serum concentration). ${ }^{[4]}$

The advantage of repeated and frequent CHP is to enhance early drug removal from serum. The plasma phenytoin half-life in overdose patient increase considerably from $24 \mathrm{~h}$ to more than $230 \mathrm{~h}$, but during $\mathrm{CHP}$ the total and free phenytoin half-life decrease to $3.9 \mathrm{~h}$ and $3.2 \mathrm{~h}$, respectively. ${ }^{[4]}$ The decrease half-life is seen only during CHP and returning to high-level post CHP. This rebound effect is due to the elevation of plasma phenytoin level as a result of redistribution from the deeper compartment. ${ }^{[2]}$ More than $90 \%$ of phenytoin is bound to albumin; this binding has a small binding constant $\left(\mathrm{k}-6 \times 10^{6} / \mathrm{mol} / \mathrm{l}\right)$ with large number $(\mathrm{n}-6)$ of binding site. ${ }^{[4,5]}$ During $\mathrm{CHP}$, the charcoal not only adsorb the free drug but also compete with the albumin for phenytoin and help in dissociation of phenytoin from albumin (low binding constant of phenytoin to albumin). ${ }^{[4,6]}$ This explain the low half-life of bound and free phenytoin during CHP. Inside the charcoal dialyzed two equilibriums exist, one between the phenytoin and albumin and another between phenytoin and activated charcoal. This explain the high extraction efficiency (up to $45 \%$ ) of phenytoin in CHP ${ }^{[6]}$ In a recent systematic review by the extracorporeal treatments in poisoning workgroup, it has been recommended that use of extracorporeal treatment (ECTR), i.e., intermittent hemodialysis preferably or intermittent hemoperfusion as an alternative, is suggested if prolong coma and/or ataxia is present or expected; and discontinuation of ECTR should be considered when clinical improvement is apparent. ${ }^{[7]}$ They also recommended that ECTR should not solely based on dose of phenytoin ingested or serum phenytoin concentration..$^{[7]}$

\section{Conclusion}

$\mathrm{CHP}$ can be an effective way to treat phenytoin toxicity when started early and repeated at frequent interval due to its small binding constant and large number of binding site. However, this was observed only in one patient, and it needs further study to evaluate the high extraction efficiency of CHP in phenytoin toxicity.

\section{Financial support and sponsorship}

Nil.

\section{Conflicts of interest}

There are no conflicts of interest.

\section{References}

1. Craig S. Phenytoin poisoning. Neurocrit Care 2005;3:161-70.

2. Craig S. Phenytoin overdose complicated by prolonged intoxication and residual neurological deficits. Emerg Med Australas 2004;16:361-5.

3. Churchwell MD, Pasko DA, Smoyer WE, Mueller BA. Enhanced clearance of highly protein-bound drugs by albumin-supplemented dialysate during modeled continuous hemodialysis. Nephrol Dial Transplant 2009;24:231-8.

4. Kawasaki C, Nishi R, Uekihara S, Hayano S, Otagiri M. Charcoal hemoperfusion in the treatment of phenytoin overdose. Am J Kidney Dis 2000;35:323-6.

5. Eyer F, Felgenhauer N, Pfab R, Thürmel K, Zilker T. Treatment of severe intravenous phenytoin overdose with hemodialysis and hemoperfusion. Med Sci Monit 2008;14:CS145-8.

6. Baehler RW, Work J, Smith W, Dominic JA. Charcoal hemoperfusion in the therapy for methsuximide and phenytoin overdose. Arch Intern Med 1980;140:1466-8.

7. Anseeuw K, Mowry JB, Burdmann EA, Ghannoum M, Hoffman RS, Gosselin S, et al. Extracorporeal treatment in phenytoin poisoning: Systematic review and recommendations from the EXTRIP (extracorporeal treatments in poisoning) workgroup. Am J Kidney Dis 2015. pii: S0272-638601258-5.

8. Kumar PP, Lingappa L, Shah MA, Shaikh FA. Charcoal hemoperfusion for phenytoin intoxication. Indian Pediatr 2012;49:152-3. 